\title{
LEVEL II SCOUR ANALYSIS FOR BRIDGE 31 (BRNATH00470031) on TOWN HIGHWAY 47, crossing LOCUST CREEK, BARNARD, VERMONT
}

U.S. Geological Survey Open-File Report 96-384

Prepared in cooperation with

VERMONT AGENCY OF TRANSPORTATION and

FEDERAL HIGHWAY ADMINISTRATION 


\section{LEVEL II SCOUR ANALYSIS FOR BRIDGE 31 (BRNATH00470031) on TOWN HIGHWAY 47, crossing LOCUST CREEK, BARNARD, VERMONT}

By Erick M. Boehmler and Micheal A. Ivanoff

U.S. Geological Survey Open-File Report 96-384

Prepared in cooperation with

VERMONT AGENCY OF TRANSPORTATION and

FEDERAL HIGHWAY ADMINISTRATION 


\title{
U.S. DEPARTMENT OF THE INTERIOR BRUCE BABBITT, Secretary
}

\author{
U.S. GEOLOGICAL SURVEY \\ Gordon P. Eaton, Director
}

For additional information write to:

District Chief

U.S. Geological Survey 361 Commerce Way

Pembroke, NH 03275-3718
Copies of this report may be purchased from:

U.S. Geological Survey Earth Science Information Center Open-File Reports Section Box 25286, MS 517 Federal Center

Denver, CO 80225 


\section{CONTENTS}

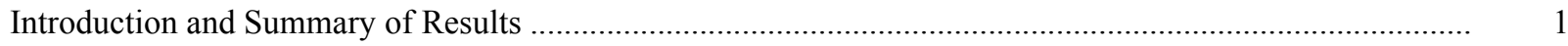

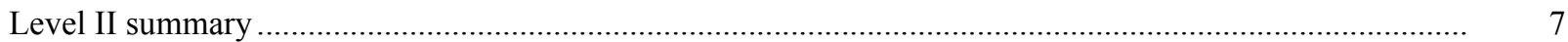

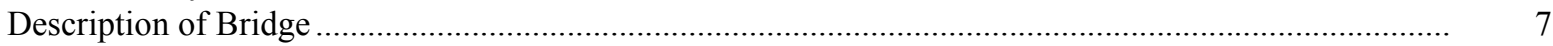

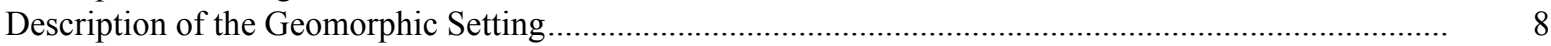

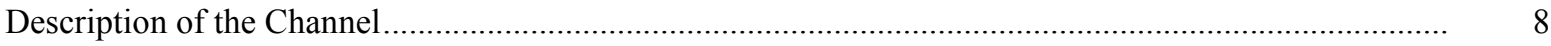

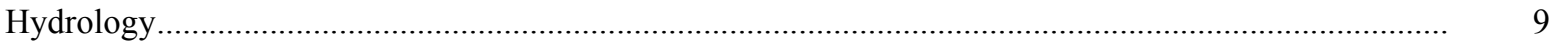

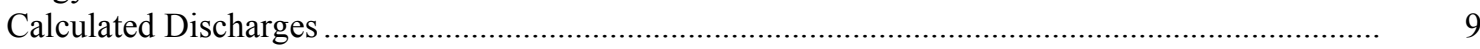

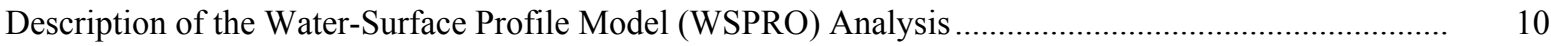

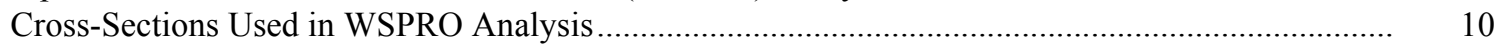

Data and Assumptions Used in WSPRO Model ..................................................................... 11

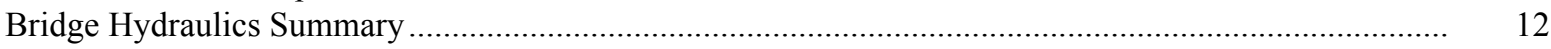

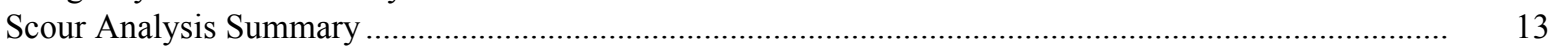

Special Conditions or Assumptions Made in Scour Analysis ...................................................... 13

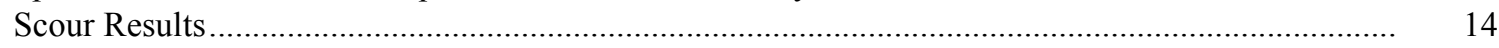

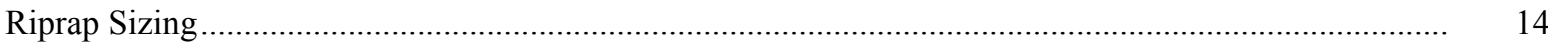

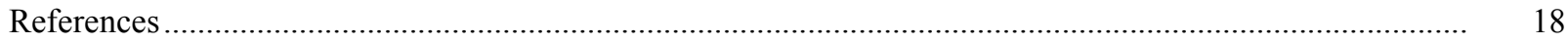

Appendixes:

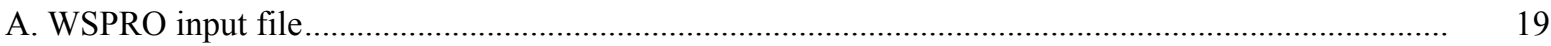

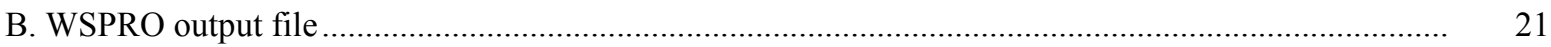

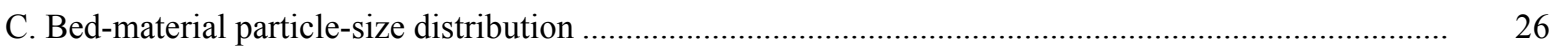

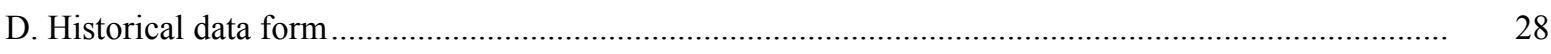

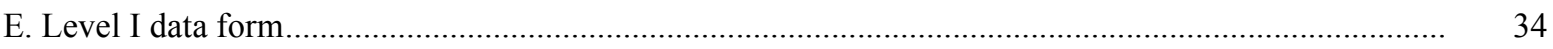

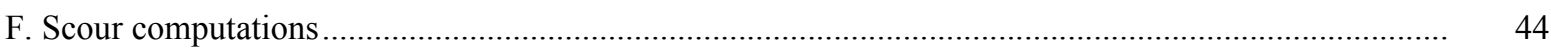

\section{FIGURES}

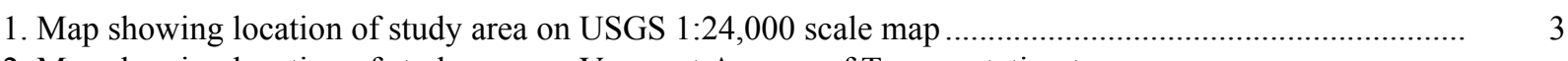

2. Map showing location of study area on Vermont Agency of Transportation town
highway map

3. Structure BRNATH00470031 viewed from upstream (October 12, 1994) ............................................ 5

4. Downstream channel viewed from structure BRNATH00470031 (October 12, 1994). .......................... 5

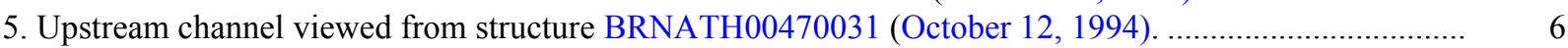

6. Structure BRNATH00470031 viewed from downstream (October 12, 1994)...................................... 6

7. Water-surface profiles for the 100- and 500-year discharges at structure

BRNATH00470031 on Town Highway 47, crossing Locust Creek,

Barnard, Vermont.

8. Scour elevations for the 100- and 500-year discharges at structure

BRNATH00470031 on Town Highway 47, crossing Locust Creek,

Barnard, Vermont.

\section{TABLES}

1. Remaining footing/pile depth at abutments for the 100-year discharge at structure

BRNATH00470031 on Town Highway 47, crossing Locust Creek,

Barnard, Vermont

2. Remaining footing/pile depth at abutments for the 500-year discharge at structure

BRNATH00470031 on Town Highway 47, crossing Locust Creek,

Barnard, Vermont.

5
(5) 


\begin{tabular}{|c|c|c|}
\hline Multiply & By & To obtain \\
\hline \multicolumn{3}{|c|}{ Length } \\
\hline inch (in.) & 25.4 & millimeter (mm) \\
\hline foot $(\mathrm{ft})$ & 0.3048 & meter $(\mathrm{m})$ \\
\hline mile (mi) & 1.609 & kilometer (km) \\
\hline \multicolumn{3}{|c|}{ Slope } \\
\hline foot per mile ( $\mathrm{ft} / \mathrm{mi})$ & 0.1894 & meter per kilometer $(\mathrm{m} / \mathrm{km})$ \\
\hline \multicolumn{3}{|c|}{ Area } \\
\hline square mile $\left(\mathrm{mi}^{2}\right)$ & 2.590 & square kilometer $\left(\mathrm{km}^{2}\right)$ \\
\hline \multicolumn{3}{|c|}{ Volume } \\
\hline cubic foot $\left(\mathrm{ft}^{3}\right)$ & $\begin{array}{l}0.02832 \\
\text { Velocity and Flow }\end{array}$ & cubic meter $\left(\mathrm{m}^{3}\right)$ \\
\hline foot per second (ft/s) & 0.3048 & meter per second $(\mathrm{m} / \mathrm{s})$ \\
\hline cubic foot per second $\left(\mathrm{ft}^{3} / \mathrm{s}\right)$ & 0.02832 & cubic meter per second $\left(\mathrm{m}^{3} / \mathrm{s}\right)$ \\
\hline $\begin{array}{l}\text { cubic foot per second per } \\
\text { square mile } \\
{\left[\left(\mathrm{ft}^{3} / \mathrm{s}\right) / \mathrm{mi}^{2}\right]}\end{array}$ & 0.01093 & $\begin{array}{l}\text { cubic meter per } \\
\text { second per square } \\
\text { kilometer }\left[\left(\mathrm{m}^{3} / \mathrm{s}\right) / \mathrm{km}^{2}\right]\end{array}$ \\
\hline
\end{tabular}

OTHER ABBREVIATIONS

$\begin{array}{lrlr}\mathrm{BF} & \text { bank full } & \text { LWW } & \text { left wingwall } \\ \mathrm{cfs} & \text { cubic feet per second } & \text { MC } & \text { main channel } \\ \mathrm{D}_{50} & \text { median diameter of bed material } & \text { RAB } & \text { right abutment } \\ \mathrm{DS} & \text { downstream } & \text { RABUT } & \text { face of right abutment } \\ \mathrm{elev} & \text { elevation } & \text { RB } & \text { right bank } \\ \mathrm{f} / \mathrm{p} & \text { flood plain } & \text { ROB } & \text { right overbank } \\ \mathrm{ft} & \text { square feet } & \text { RWW } & \text { right wingwall } \\ \mathrm{ft} / \mathrm{ft} & \text { feet per foot } & \text { TH } & \text { town highway } \\ \mathrm{JCT} & \text { junction } & \text { UB } & \text { under bridge } \\ \mathrm{LAB} & \text { left abutment } & \text { US } & \text { upstream } \\ \mathrm{LABUT} & \text { face of left abutment } & \text { USGS } & \text { United States Geological Survey } \\ \text { LB } & \text { left bank } & \text { VTAOT Vermont Agency of Transportation } \\ \text { LOB } & \text { left overbank } & \text { WSPRO } & \text { water-surface profile model }\end{array}$

In this report, the words "right" and "left" refer to directions that would be reported by an observer facing downstream. Sea level: In this report, "sea level" refers to the National Geodetic Vertical Datum of 1929-- a geodetic datum derived from a general adjustment of the first-order level nets of the United States and Canada, formerly called Sea Level Datum of 1929.

In the appendices, the above abbreviations may be combined. For example, USLB would represent upstream left bank. 


\title{
LEVEL II SCOUR ANALYSIS FOR BRIDGE 31 (BRNATH00470031) ON TOWN HIGHWAY 47, CROSSING LOCUST CREEK, BARNARD, VERMONT
}

\author{
By Erick M. Boehmler and Micheal A. Ivanoff
}

\section{INTRODUCTION AND SUMMARY OF RESULTS}

This report provides the results of a detailed Level II analysis of scour potential at structure BRNATH00470031 on town highway 47 crossing Locust Creek, Barnard, Vermont (figures 1-8). A Level II study is a basic engineering analysis of the site, including a quantitative analysis of stream stability and scour (U.S. Department of Transportation, 1993). A Level I study is included in Appendix E of this report. A Level I study provides a qualitative geomorphic characterization of the study site. Information on the bridge, gleaned from VTAOT files, was compiled prior to conducting Level I and Level II analyses and can be found in Appendix D.

The site is in the Green Mountain physiographic province of central Vermont in the town of Barnard. The $4.47-\mathrm{mi}^{2}$ drainage area is a predominantly rural and forested basin. In the vicinity of the study site, the banks have dense woody vegetation coverage except for areas of grass and brush on the upstream banks.

In the study area, Locust Creek has an incised, sinuous channel with a slope of approximately $0.006 \mathrm{ft} / \mathrm{ft}$, an average channel top width of $34 \mathrm{ft}$ and an average channel depth of $3 \mathrm{ft}$. The predominant channel bed materials are gravel and cobble $\left(\mathrm{D}_{50}\right.$ is $55.2 \mathrm{~mm}$ or $0.181 \mathrm{ft}$ ). The geomorphic assessment at the time of the Level I and Level II site visit on October 12, 1994, indicated that the reach was stable.

The town highway 47 crossing of Locust Creek is a 28 -ft-long, one-lane bridge consisting of one 25-foot span concrete slab superstructure (Vermont Agency of Transportation, written commun., August 23, 1994). The bridge is supported by vertical, concrete abutments with concrete wingwalls. The channel is skewed approximately 20 degrees to the opening while the opening-skew-to-roadway is 15 degrees.

The scour protection measures at the site were type- 2 stone fill (less than 36 inches diameter) on the right and left abutments and all wingwalls. The banks upstream and downstream are not protected. Additional details describing conditions at the site are included in the Level II Summary and Appendices D and E. 
Scour depths and rock rip-rap sizes were computed using the general guidelines described in Hydraulic Engineering Circular 18 (Richardson and others, 1993). Total scour at a highway crossing is comprised of three components: 1) long-term streambed degradation; 2) contraction scour (due to accelerated flow caused by a reduction in flow area at a bridge) and; 3) local scour (caused by accelerated flow around piers and abutments). Total scour is the sum of the three components. Equations are available to compute depths for contraction and local scour and a summary of the results of these computations follows.

Contraction scour for all modelled flows ranged from 0.0 to $1.5 \mathrm{ft}$. The worst-case contraction scour occurred at the 500-year discharge. Abutment scour ranged from 6.6 to $9.2 \mathrm{ft}$. The worst-case abutment scour also occurred at the 500-year discharge. Additional information on scour depths and depths to armoring are included in the section titled "Scour Results". Scoured-streambed elevations, based on the calculated scour depths, are presented in tables 1 and 2. A cross-section of the scour computed at the bridge is presented in figure 8. Scour depths were calculated assuming an infinite depth of erosive material and a homogeneous particle-size distribution.

It is generally accepted that the Froehlich equation (abutment scour) gives "excessively conservative estimates of scour depths" (Richardson and others, 1993, p. 48). Usually, computed scour depths are evaluated in combination with other information including (but not limited to) historical performance during flood events, the geomorphic stability assessment, existing scour protection measures, and the results of the hydraulic analyses. Therefore, scour depths adopted by VTAOT may differ from the computed values documented herein. 


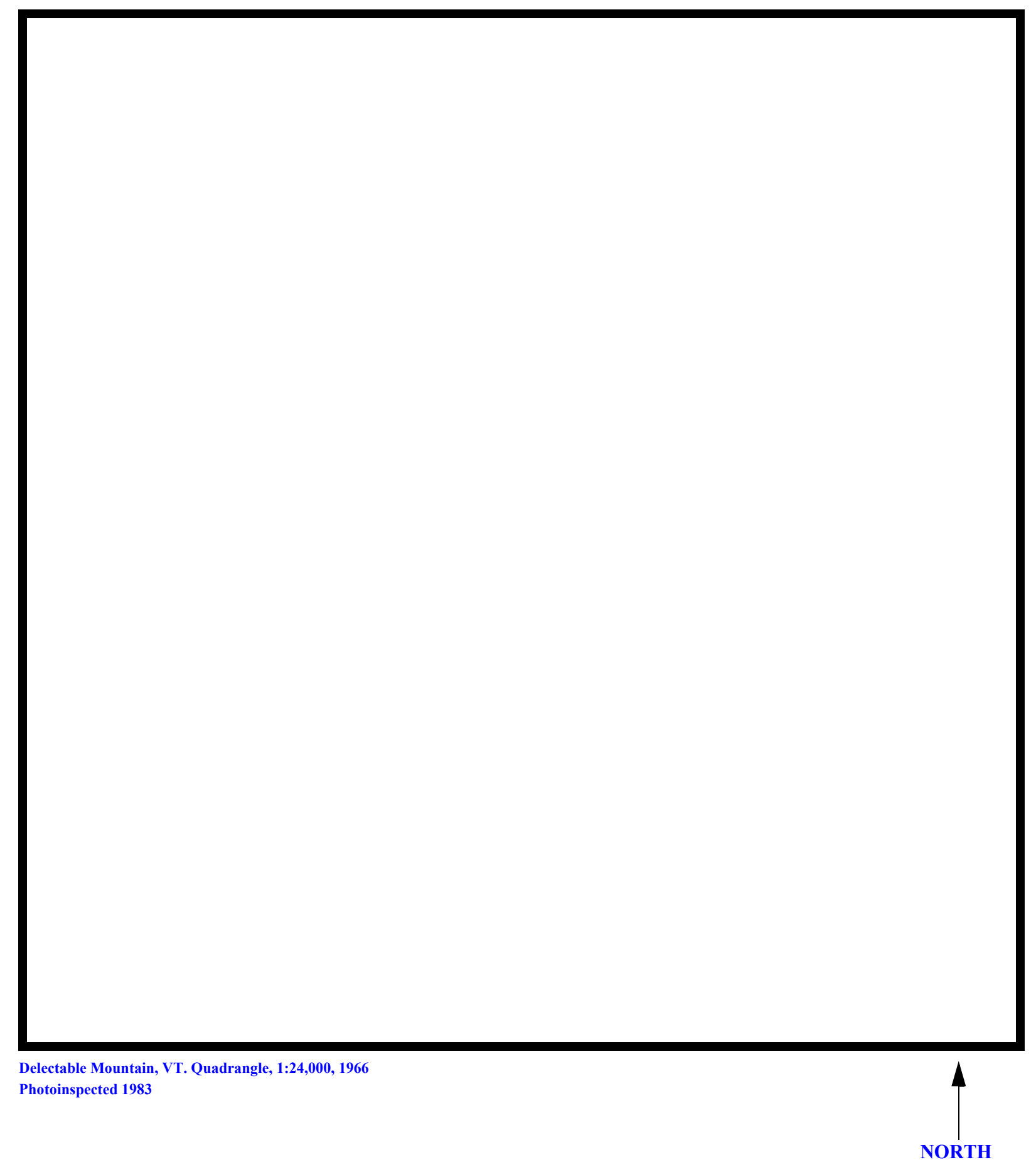

Figure 1. Location of study area on USGS 1:24,000 scale map. 
Figure 2. Location of study area on Vermont Agency of Transportation town highway map. 

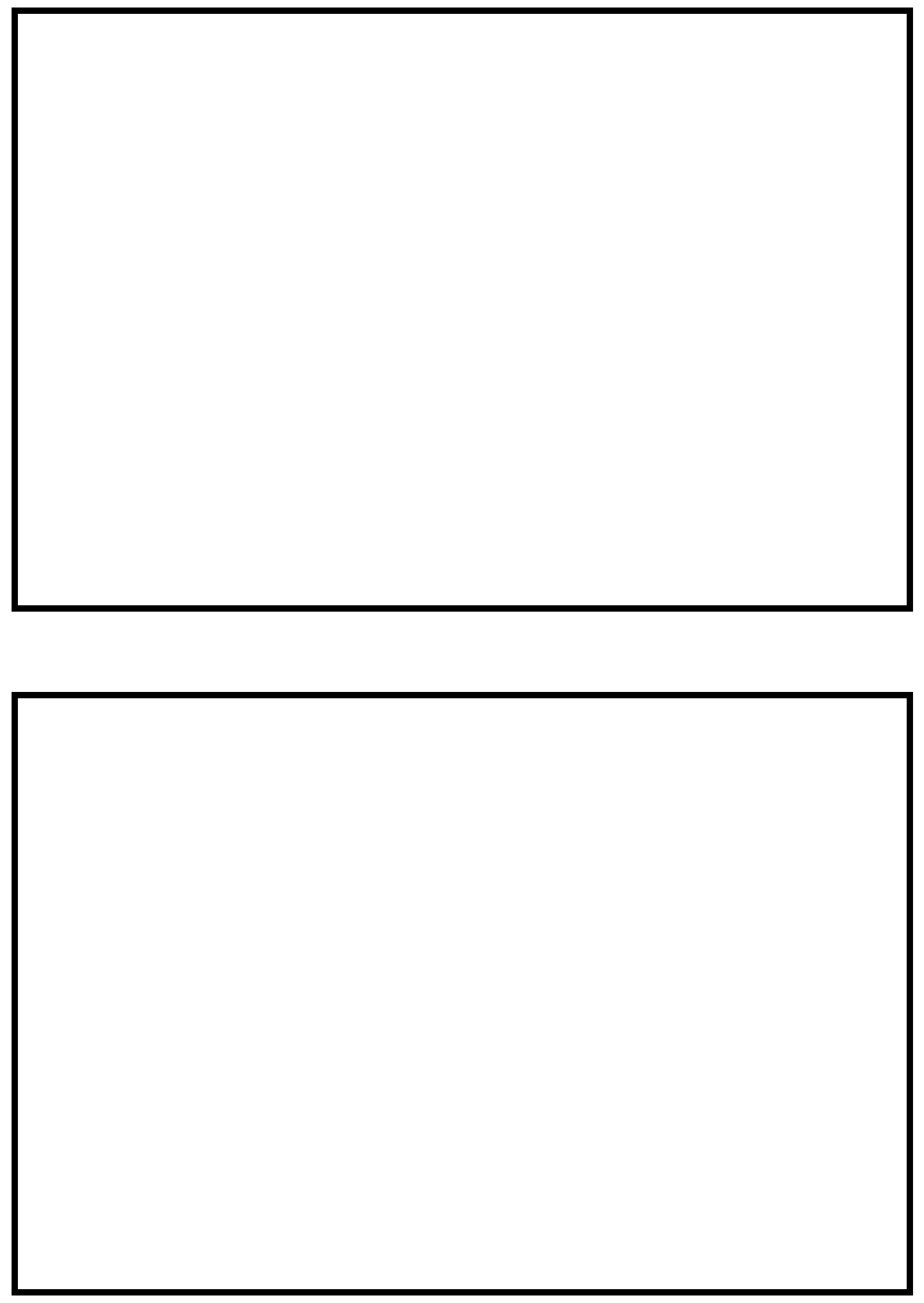

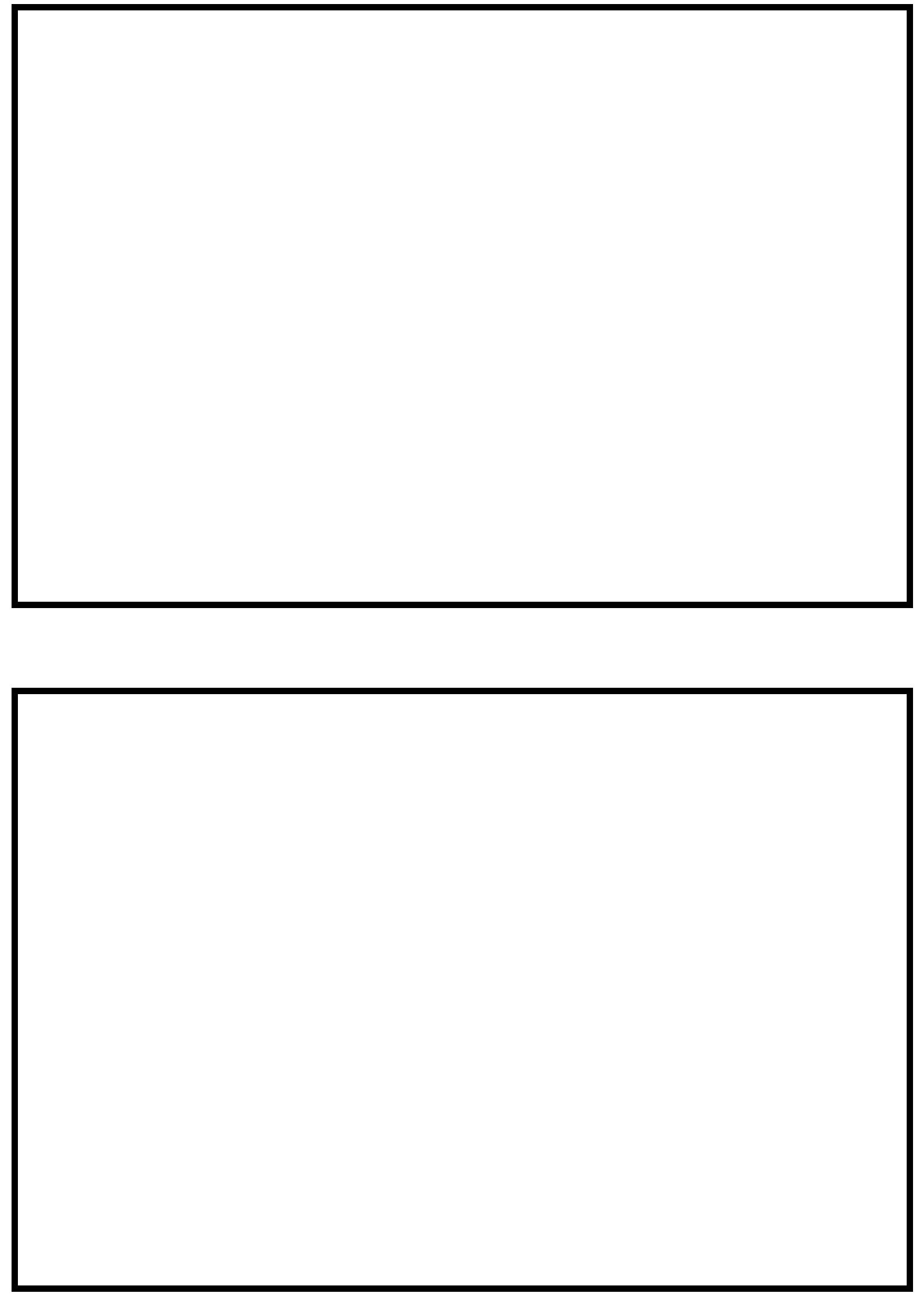


\section{LEVEL II SUMMARY}

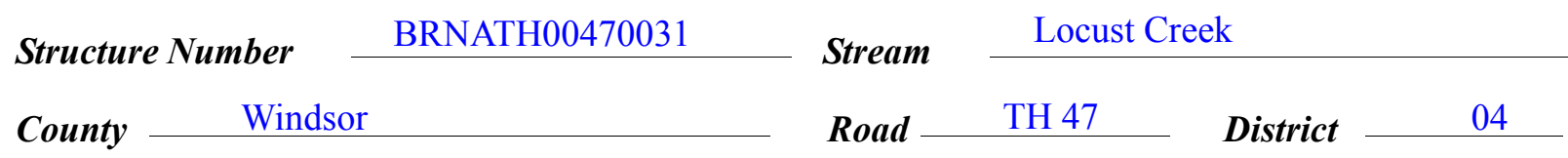

\section{Description of Bridge}

Bridge length $\stackrel{28}{2} \boldsymbol{f t}$ Bridge width $\stackrel{17.5}{f t}$ Max span length $\stackrel{25}{ } \boldsymbol{f t}$ Alignment of bridge to road (on curve or straight)

Abutment type Vertical

Stone fill on abutment?

nasmintins af atom n fill Yes

\section{Embankment type}

Dato af insnortion Type-2 on the right and left abutments, upstream left and right
Vertical

$10 / 12 / 94$

wingwall, and downstream left and right wingwall.

Abutments and wingwalls are concrete.

- . . . . . . . .

\section{$\mathrm{Y}$}

Is bridge skewed to flood flow according to N r survey? Angle

20

Is bridge skewed to flood flow according to N r survey? Angle

Debris accumulation on bridge at time of Level I or Level II site visit:

\begin{tabular}{|c|c|c|c|}
\hline & $\begin{array}{c}\text { Date of insnortion } \\
10 / 12 / 94 \\
\end{array}$ & $\begin{array}{l}\text { Percent of alommal } \\
\text { blocked hortzontatly }\end{array}$ & $\begin{array}{l}\text { Percent of } 0 \\
\text { blocked verticatty }\end{array}$ \\
\hline & $10 / 12 / 94$ & -- & -- \\
\hline
\end{tabular}

Level II

Moderate. While the channel is stable overall, there is some

localized zones of lateral instability noted with a high percentage of bank tree cover.

Potential for debris

On 10/12/94, the stone fill along the abutments was noted to constrict flow in the lowest quarter Dosrriho anv fonturos noar ar at tho hridos that mav affort flow, (includo ahsorvation dato) of the bridge opening. 


\section{Description of the Geomorphic Setting}

General topography The channel is located within a 185 foot-wide valley, with steep to moderately sloping valley walls on both sides.

Geomorphic conditions at bridge site: downstream (DS), upstream (US)

Date of inspection $\quad 10 / 12 / 94$

DS left: $\quad$ Gradually sloping channel bank to steep valley wall.

DS right: $\quad$ Gradually sloping channel bank to moderately sloping valley wall.

US left: $\quad$ Moderately sloping channel bank to steep valley wall

US right: $\quad$ Moderately sloping channel bank to moderately sloped valley wall.

\section{Description of the Channel}

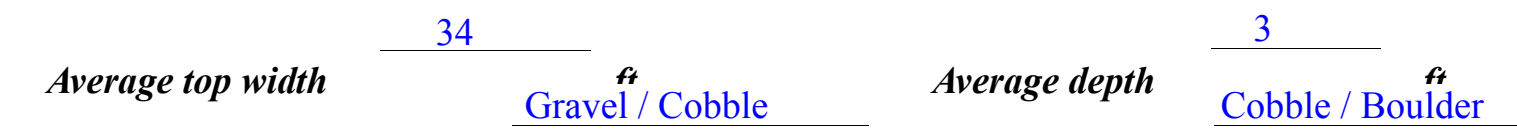

Predominant bed material

Bank material

Sinuous but stable

with semi-allúvial to non-alluvial channei boundaries and no flöo p̈lains.

$10 / 12 / 94$

Vegetative co 1 Trees and shrübs

DS left: $\quad$ Trees, shrubs, and brush

DS right: $\quad$ Grass and brush giving way to trees and brush.

US left: $\quad$ Grass and brush giving way to trees, shrubs, and brush.

US right: $\quad \underline{\mathrm{Y}}$

Do banks appear stable? Localized zones of instability are evident beyond the study area. A

cut-bank is noted on the left bank upstream with some trees leaning over the channel.
date of observatton.

The assessment of 10/12/94 indicated the stone fill on each abutment constricts the lowest

quarter of the channel

through the bridge.

Describe any obstructions in channel and date of observation. 


\title{
Hydrology
}

Drainage area $\stackrel{4.47}{\boldsymbol{m i}^{2}}$

Percentage of drainage area in physiographic provinces: (approximate)

Physiographic province

Green Mountain
Percent of drainage area

100

\begin{abstract}
Is drainage area considered rural or urban?
Rural urbanization: None.

Describe any significant
\end{abstract}

Is there a USGS gage on the stream of interest?

No

\section{USGS gage description}

USGS gage number

Gage drainage area

$m i^{2}$

No

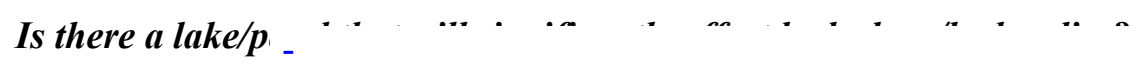

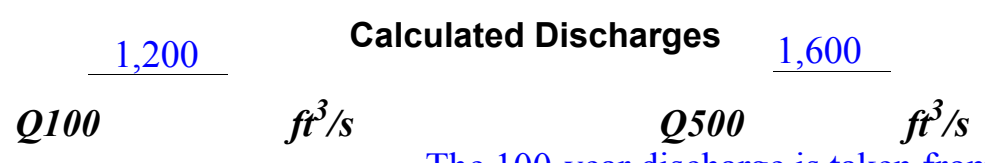

The 100-year discharge is taken from flood

frequency estimates in the VTAOT database (VTAOT, written communication, May 4, 1995).

The 500-year discharge was extrapolated from the available data. The discharges used in the model were in a range defined by several empirical methods (Potter, 1957a\&b; Johnson and Tasker, 1974; Benson, 1962; FHWA, 1983; Talbot, 1887). 


\section{Description of the Water-Surface Profile Model (WSPRO) Analysis}

Datum for WSPRO analysis (USGS survey, sea level, VTAOT plans)

USGS survey

Datum tie between USGS survey and VTAOT plans

Add 1597 feet to the USGS

survey to obtain VTAOT plan's datum.

Description of reference marks used to determine USGS datum. $\quad$ RM1 is a chiseled " $X$ "

on top of the DS end of the right abutment (elev. $96.76 \mathrm{ft}$, arbitrary datum). RM2 is a chiseled

"X" on top of the US end of the right abutment (elev. $96.92 \mathrm{ft}$, arbitrary datum).

\section{Cross-Sections Used in WSPRO Analysis}

\begin{tabular}{|c|c|c|c|}
\hline${ }^{1}$ Cross-section & $\begin{array}{c}\text { Section } \\
\text { Reference } \\
\text { Distance } \\
\text { (SRD) in feet }\end{array}$ & $\begin{array}{c}{ }^{2} \text { Cross-section } \\
\text { development }\end{array}$ & Comments \\
\hline EXITX & -36 & 1 & Exit section \\
\hline FULLV & 0 & 2 & $\begin{array}{l}\text { Downstream Full-valley } \\
\text { section (Templated from } \\
\text { EXITX) }\end{array}$ \\
\hline BRIDG & 0 & 1 & Bridge section \\
\hline RDWAY & 12 & 1 & Road Grade section \\
\hline APPRO & 47 & 2 & $\begin{array}{l}\text { Modelled Approach sec- } \\
\text { tion (Templated from } \\
\text { APTEM) }\end{array}$ \\
\hline APTEM & 59 & 1 & $\begin{array}{l}\text { Approach section as sur- } \\
\text { veyed (Used as a tem- } \\
\text { plate) }\end{array}$ \\
\hline
\end{tabular}

${ }^{1}$ For location of cross-sections see plan-view sketch included with Level I field form, Appendix E.

For more detail on how cross-sections were developed see WSPRO input file. 


\section{Data and Assumptions Used in WSPRO Model}

Hydraulic analyses of the reach were done by use of the Federal Highway Administration's WSPRO step-backwater computer program (Shearman and others, 1986, and

Shearman, 1990). Results of the hydraulic model are presented in the Bridge Hydraulic Summary, Appendix B, and figure 7.

Channel roughness factors (Manning's " $\mathrm{n}$ ") used in the hydraulic model were estimated using field inspections at each cross section following the general guidelines described by Arcement and Schneider (1989). Final adjustments to the values were made during the modelling of the reach. Channel " $\mathrm{n}$ " values for the reach ranged from 0.045 to 0.060 .

Normal depth at the exit section (EXITX) was assumed as the starting water surface. This depth was computed by use of the slope-conveyance method outlined in the user's manual for WSPRO (Shearman, 1990). The slope used was $0.006 \mathrm{ft} / \mathrm{ft}$ which was estimated from surveyed thalweg points downstream of the site.

The surveyed approach section (APTEM) was moved along the approach channel slope $(0.0291 \mathrm{ft} / \mathrm{ft})$ to establish the modelled approach section (APPRO), one bridge length upstream of the upstream face as recommended by Shearman and others (1986). This approach also provides a consistent method for determining scour variables.

The modeled 100- and 500-year discharges do not overtop the roadway embankments or the bridge deck.

Although the upstream channel is skewed to the bridge opening, flow was assumed to align with the abutment walls when passing through the bridge. 


\section{Bridge Hydraulics Summary}

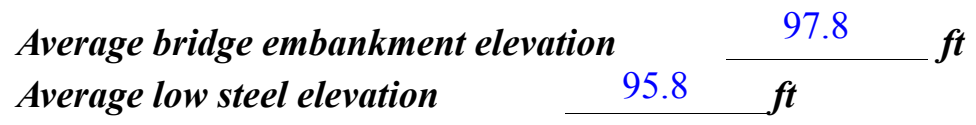

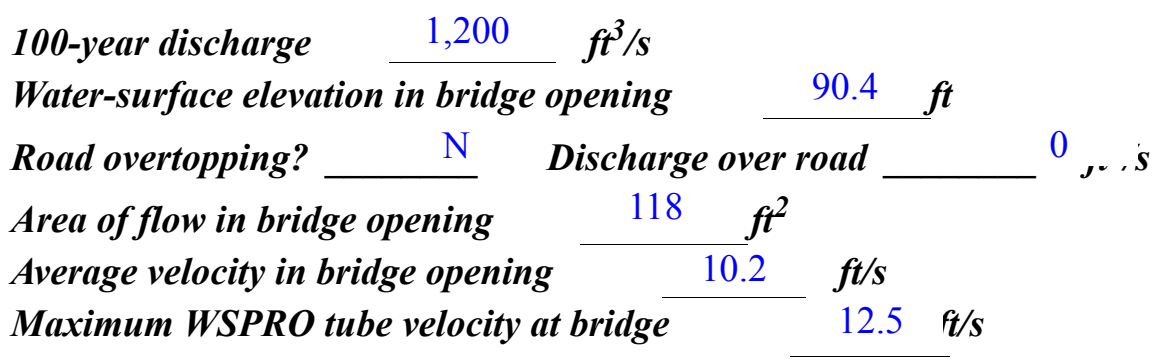

Water-surface elevation at Approach section with bridge

Water-surface elevation at Approach section without bridge

Amount of backwater caused by bridge

$0.5 \quad$ it

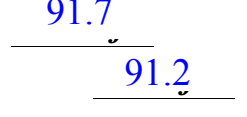

500-year discharge $\quad 1,600 \quad \mathrm{ft}^{3} / \mathrm{s}$

Water-surface elevation in bridge opening

Road overtopping?

$\mathrm{N}$

Discharge over road

$91.3 \boldsymbol{f t}$

Area of flow in bridge opening

Average velocity in bridge opening 137 $f t^{2}$

Maximum WSPRO tube velocity at bridge $11.7 \mathrm{ft} / \mathrm{s}$

14.6

$0, j / s$

Water-surface elevation at Approach section with bridge

Water-surface elevation at Approach section without bridge

93.2

Amount of backwater caused by bridge

1.0

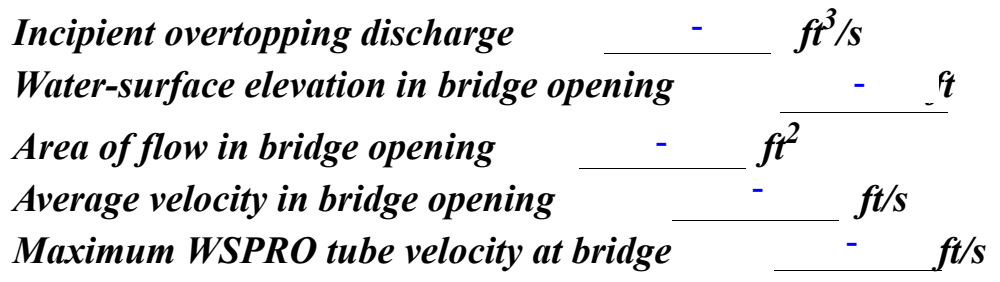

Water-surface elevation at Approach section with bridge

Water-surface elevation at Approach section without bridge

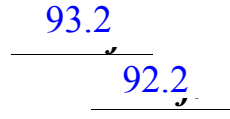
Amount of backwater caused by bridge

$-\quad t$




\section{Scour Analysis Summary}

\section{Special Conditions or Assumptions Made in Scour Analysis}

Scour depths were computed using the general guidelines described in Hydraulic Engineering Circular 18 (Richardson and others, 1993). Scour depths were calculated assuming an infinite depth of erosive material and a homogeneous particle-size distribution. The results of the scour analysis are presented in tables 1 and 2 and a graph of the scour depths is presented in figure 8 .

Contraction scour was computed by use of the clear-water contraction scour equation (Richardson and others, 1993, p. 35, equation 18) for the 500-year discharge. For the 100year discharge, contraction scour was computed by use of the live-bed contraction scour equation (Richardson and others, 1993, p. 33, equation 16). For contraction scour computations, the average depth in the contracted section (AREA/TOPWIDTH) is subtracted from the depth of flow computed by the scour equation (Y2) to determine the actual amount of scour. In this case, the 500-year discharge model resulted in the worst case contraction scour with a scour depth of $1.5 \mathrm{ft}$. Armoring depths computed suggest that streambed armoring will not limit the depth of contraction scour.

Abutment scour for each modelled discharge was computed by use of the Froehlich equation (Richardson and others, 1993, p. 49, equation 24). Variables for the Froehlich equation include the Froude number of the flow approaching the embankments, the length of the embankment blocking flow, and the depth of flow approaching the embankment less any roadway overtopping. 


\section{Scour Results}
Incipient
overtopping
Contraction scour:
100-yr discharge 500-yr discharge discharge
(Scour depths in feet)

Main channel

Live-bed scour

Clear-water scour

Depth to armoring

Left overbank

Right overbank

Local scour:

Abutment scour

Left abutment

Right abutment

Pier scour

Pier 1

Pier 2

Pier 3
7.1

$6.6-$
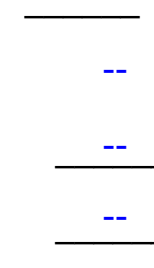

9.2

$7.8-$
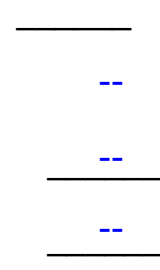

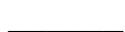

$-$

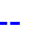

$--$

$--^{-}$

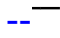

\section{Riprap Sizing}

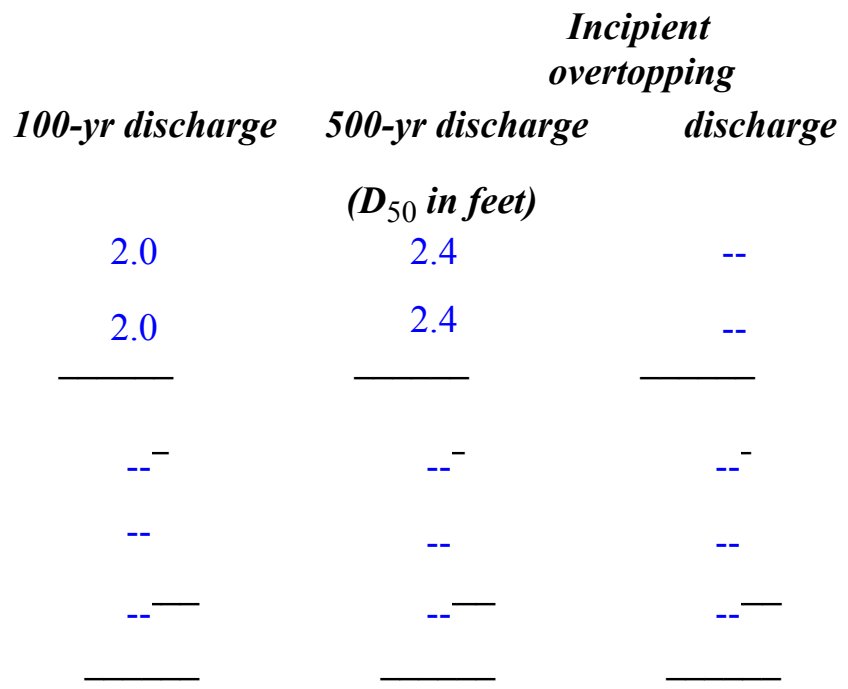




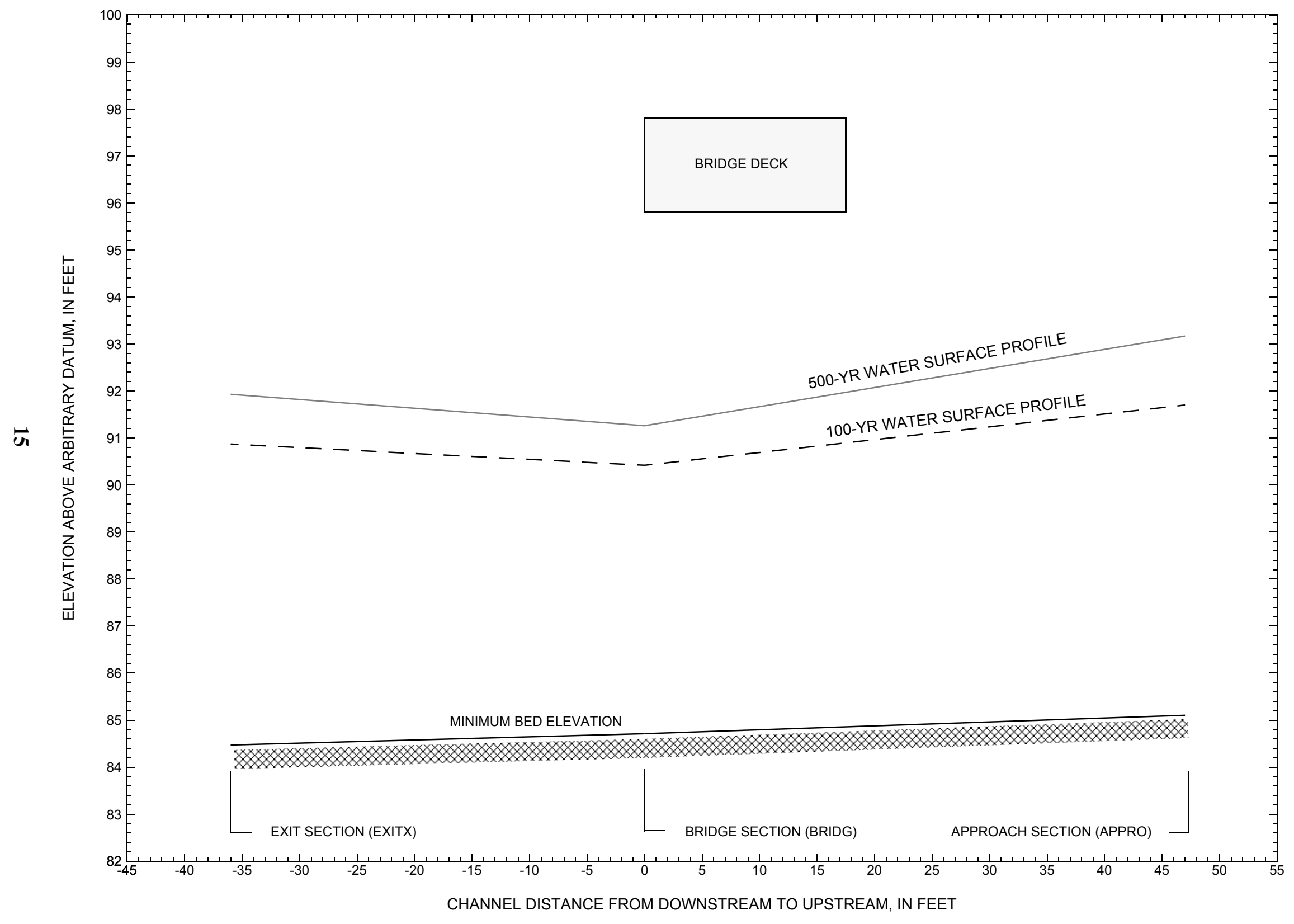

Figure 7. Water-surface profiles for the 100- and 500-yr discharges at structure BRNATH00470031 on town highway 47, crossing Locust Creek, Barnard, Vermont. 


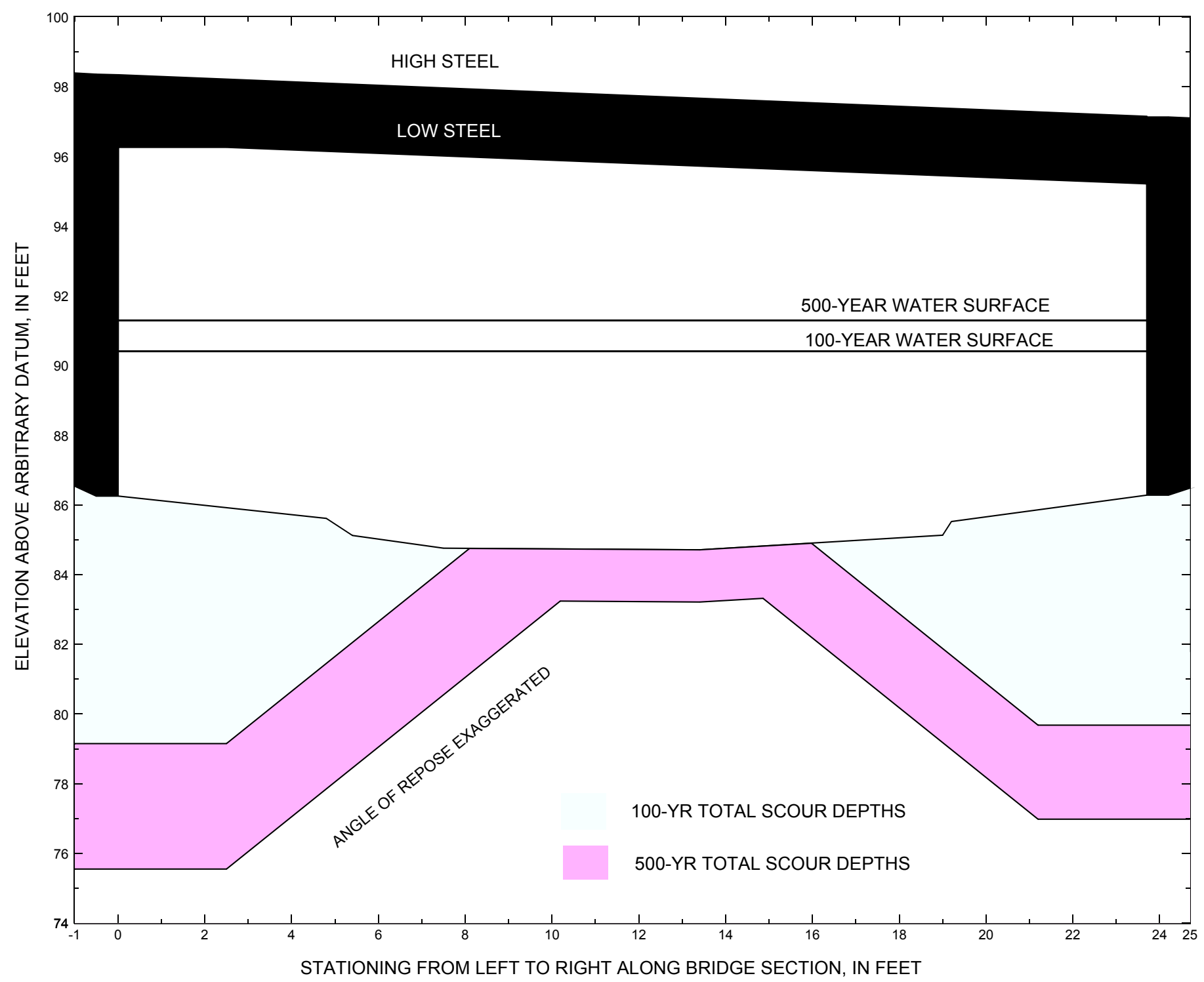

Figure 8. Scour elevations for the 100-yr and 500-yr discharges at structure BRNATH00470031 on town highway 47, crossing Locust Creek, Barnard, Vermont. 
Table 1. Remaining footing/pile depth at abutments for the 100-year discharge at structure BRNATH00470031 on Town Highway 47, crossing Locust Creek, Barnard, Vermont.

[VTAOT, Vermont Agency of Transportation; --,no data]

\begin{tabular}{|c|c|c|c|c|c|c|c|c|c|c|c|}
\hline Description & Station $^{1}$ & $\begin{array}{l}\text { VTAOT } \\
\text { plans' } \\
\text { bridge seat } \\
\text { elevation } \\
\text { (feet) }\end{array}$ & $\begin{array}{l}\text { Surveyed } \\
\text { minimum } \\
\text { low-chord } \\
\text { elevation } \\
\quad \text { (feet) }\end{array}$ & $\begin{array}{c}\text { Bottom of } \\
\text { footing } \\
\text { elevation } \\
\text { (feet) }\end{array}$ & $\begin{array}{c}\text { Channel } \\
\text { elevation at } \\
\text { abutment/ } \\
\text { pier }^{2} \\
\text { (feet) }\end{array}$ & $\begin{array}{l}\text { Contraction } \\
\text { scour depth } \\
\text { (feet) }\end{array}$ & $\begin{array}{l}\text { Abutment } \\
\text { scour } \\
\text { depth } \\
\text { (feet) }\end{array}$ & $\begin{array}{l}\text { Pier } \\
\text { scour } \\
\text { depth } \\
\text { (feet) }\end{array}$ & $\begin{array}{l}\text { Depth of } \\
\text { total scour } \\
\text { (feet) }\end{array}$ & $\begin{array}{c}\text { Elevation of } \\
\text { scour }^{2} \\
\text { (feet) }\end{array}$ & $\begin{array}{c}\text { Remaining } \\
\text { footing/pile } \\
\text { depth } \\
\text { (feet) }\end{array}$ \\
\hline \multicolumn{12}{|c|}{100 -yr. discharge is 1,200 cubic-feet per second } \\
\hline Left abutment & 0.0 & 1693.6 & 96.4 & 82 & 86.2 & 0.0 & 7.1 & -- & 7.1 & 79.1 & -3 \\
\hline Right abutment & 23.7 & 1692.4 & 95.2 & 82 & 86.3 & 0.0 & 6.6 & -- & 6.6 & 79.7 & -2 \\
\hline
\end{tabular}

1. Measured along the face of the most constricting side of the bridge.

2. Arbitrary datum for this study.

Table 2. Remaining footing/pile depth at abutments for the 500-year discharge at structure BRNATH00470031 on Town Highway 47, crossing Locust Creek, Barnard, Vermont.

[VTAOT, Vermont Agency of Transportation; --, no data]

\begin{tabular}{|c|c|c|c|c|c|c|c|c|c|c|c|}
\hline Description & Station $^{1}$ & $\begin{array}{c}\text { VTAOT } \\
\text { plans' } \\
\text { bridge seat } \\
\text { elevation } \\
\text { (feet) }\end{array}$ & $\begin{array}{l}\text { Surveyed } \\
\text { minimum } \\
\text { low-chord } \\
\text { elevation } \\
\quad \text { (feet) }\end{array}$ & $\begin{array}{l}\text { Bottom of } \\
\text { footing } \\
\text { elevation } \\
\text { (feet) }\end{array}$ & $\begin{array}{c}\text { Channel } \\
\text { elevation at } \\
\text { abutment/ } \\
\text { pier }^{2} \\
\text { (feet) }\end{array}$ & $\begin{array}{l}\text { Contraction } \\
\text { scour depth } \\
\text { (feet) }\end{array}$ & $\begin{array}{l}\text { Abutment } \\
\text { scour } \\
\text { depth } \\
\text { (feet) }\end{array}$ & $\begin{array}{l}\text { Pier } \\
\text { scour } \\
\text { depth } \\
\text { (feet) }\end{array}$ & $\begin{array}{l}\text { Depth of } \\
\text { total scour } \\
\text { (feet) }\end{array}$ & $\begin{array}{c}\text { Elevation of } \\
\text { scour }^{2} \\
\text { (feet) }\end{array}$ & $\begin{array}{c}\text { Remaining } \\
\text { footing/pile } \\
\text { depth } \\
\text { (feet) }\end{array}$ \\
\hline \multicolumn{12}{|c|}{500 -yr. discharge is 1,600 cubic-feet per second } \\
\hline Left abutment & 0.0 & 1693.6 & 96.4 & 82 & 86.2 & 1.5 & 9.2 & -- & 10.7 & 75.5 & -7 \\
\hline Right abutment & 23.7 & 1692.4 & 95.2 & 82 & 86.3 & 1.5 & 7.8 & -- & 9.3 & 77.0 & -5 \\
\hline
\end{tabular}

1. Measured along the face of the most constricting side of the bridge.

2. Arbitrary datum for this study. 


\section{SELECTED REFERENCES}

Arcement, G.J., Jr., and Schneider, V.R., 1989, Guide for selecting Manning's roughness coefficients for natural channels and flood plains: U.S. Geological Survey Water-Supply Paper 2339, 38 p.

Barnes, H.H., Jr., 1967, Roughness characteristics of natural channels: U.S. Geological Survey Water-Supply Paper 1849, 213 p.

Benson, M.A., 1962, Factors Influencing the Occurrence of Floods in a Humid Region of Diverse Terraine, U.S. Geological Survey Water-supply Paper 1580-B, 64 p.

Brown, S.A. and Clyde, E.S., 1989, Design of riprap revetment: Federal Highway Administration Hydraulic Engineering Circular No. 11, Publication FHWA-IP-89-016, 156 p.

Federal Highway Administration, 1983, Runoff estimates for small watersheds and development of sound design: Federal Highway Administration Report FHWA-RD-77-158

Froehlich, D.C., 1989, Local scour at bridge abutments in Ports, M.A., ed., Hydraulic Engineering--Proceedings of the 1989 National Conference on Hydraulic Engineering: New York, American Society of Civil Engineers, p. 13-18.

Hayes, D.C.,1993, Site selection and collection of bridge-scour data in Delaware, Maryland, and Virginia: U.S. Geological Survey Water-Resources Investigation Report 93-4017, 23 p.

Johnson, C.G. and Tasker, G.D.,1974, Progress report on flood magnitude and frequency of Vermont streams: U.S. Geological Survey Open-File Report 74-130, 37 p.

Laursen, E.M., 1960, Scour at bridge crossings: Journal of the Hydraulics Division, American Society of Civil Engineers, v. 86, no. HY2, p. 39-53.

Potter, W. D., 1957a, Peak rates of runoff in the Adirondack, White Mountains, and Maine woods area, Bureau of Public Roads

Potter, W. D., 1957b, Peak rates of runoff in the New England Hill and Lowland area, Bureau of Public Roads

Richardson, E.V., Harrison, L.J., Richardson, J.R., and Davis, S.R., 1993, Evaluating scour at bridges: Federal Highway Administration Hydraulic Engineering Circular No. 18, Publication FHWA-IP-90-017, 131 p.

Richardson, E.V., Simons, D.B., and Julien, P.Y., 1990, Highways in the river environment: Federal Highway Administration Publication FHWA-HI-90-016.

Ritter, D.F., 1984, Process Geomorphology: W.C. Brown Co., Debuque, Iowa, 603 p.

Shearman, J.O., 1990, User's manual for WSPRO--a computer model for water surface profile computations: Federal Highway Administration Publication FHWA-IP-89-027, 187 p.

Shearman, J.O., Kirby, W.H., Schneider, V.R., and Flippo, H.N., 1986, Bridge waterways analysis model; research report: Federal Highway Administration Publication FHWA-RD-86-108, 112 p.

Talbot, A.N., 1887, The determination of water-way for bridges and culverts.

U.S. Department of Transportation, 1993, Stream stability and scour at highway bridges, Participant Workbook: Federal Highway Administration Publication FHWA HI-91-011.

U.S. Geological Survey, 1966, Delectable Mountain, Vermont 7.5 Minute Series quadrangle map: U.S. Geological Survey Topographic Maps, Aerial Photographs, 1964; Photoinspected 1983, Scale 1:24,000, Contour Interval, 20 feet. 


\section{APPENDIX A: \\ WSPRO INPUT FILE}




\section{WSPRO INPUT FILE}

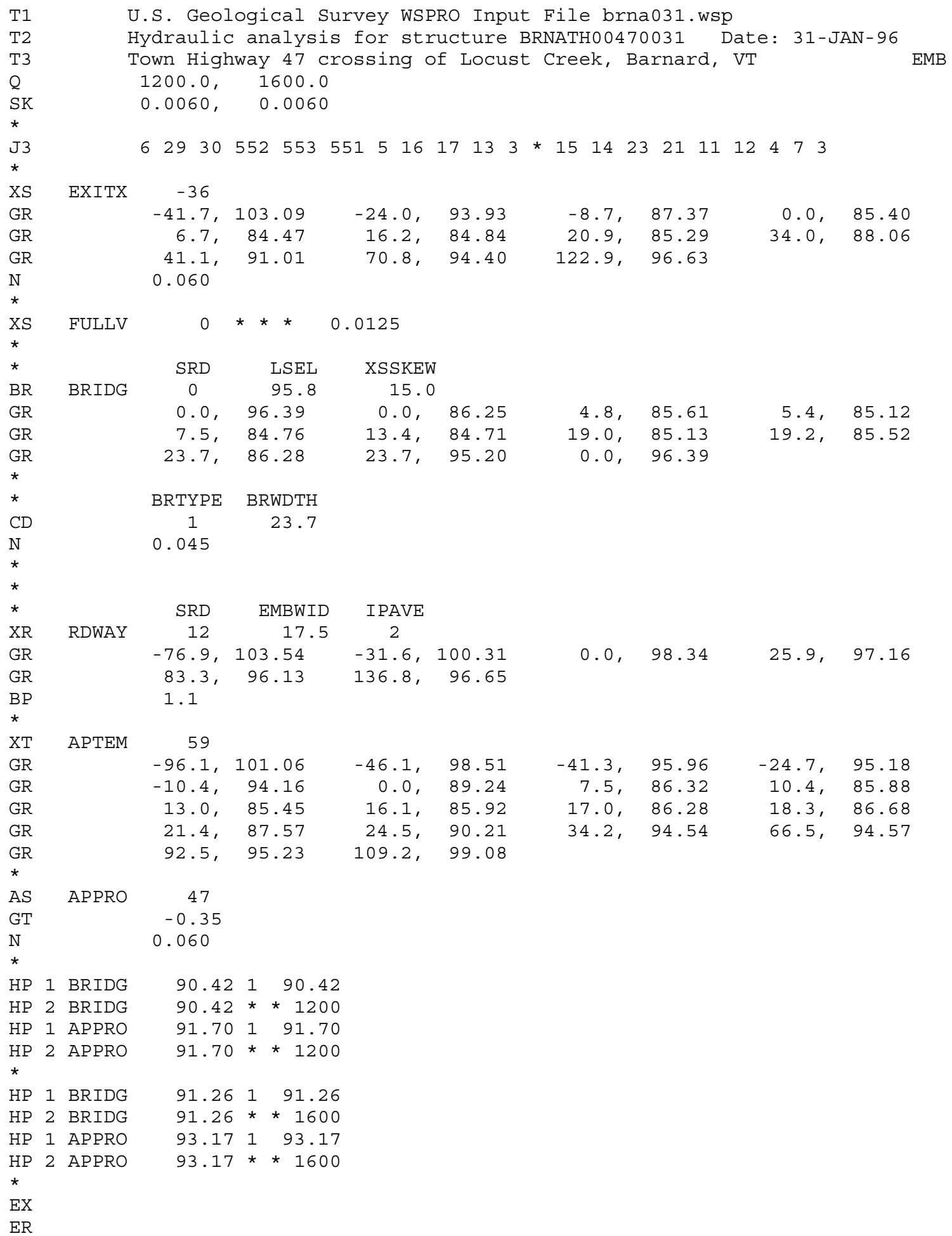




\section{APPENDIX B: \\ WSPRO OUTPUT FILE}


WSPRO OUTPUT FILE

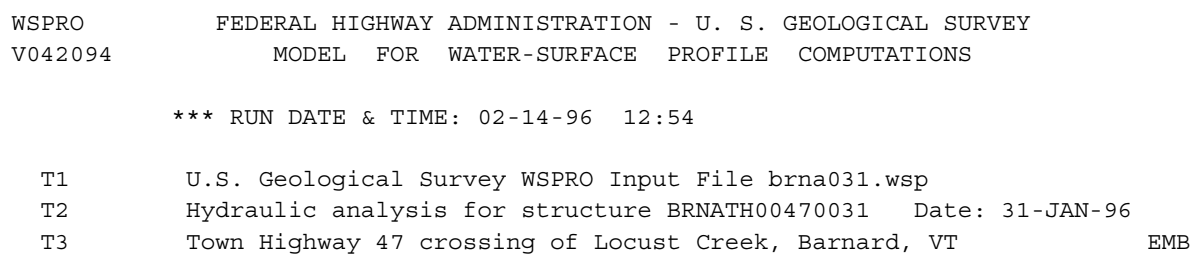

$\begin{array}{rrrrrrrrrr}\text { WSEL } & \text { SA\# } & \text { AREA } & \text { K } & \text { TOPW } & \text { WETP } & \text { ALPH } & \text { LEW } & \text { REW } & \text { QCR } \\ & 1 & 137 & 11591 & 23 & 33 & & & & 1899 \\ 91.26 & & 137 & 11591 & 23 & 33 & 1.00 & 0 & 24 & 1899\end{array}$


WSPRO OUTPUT FILE (continued)

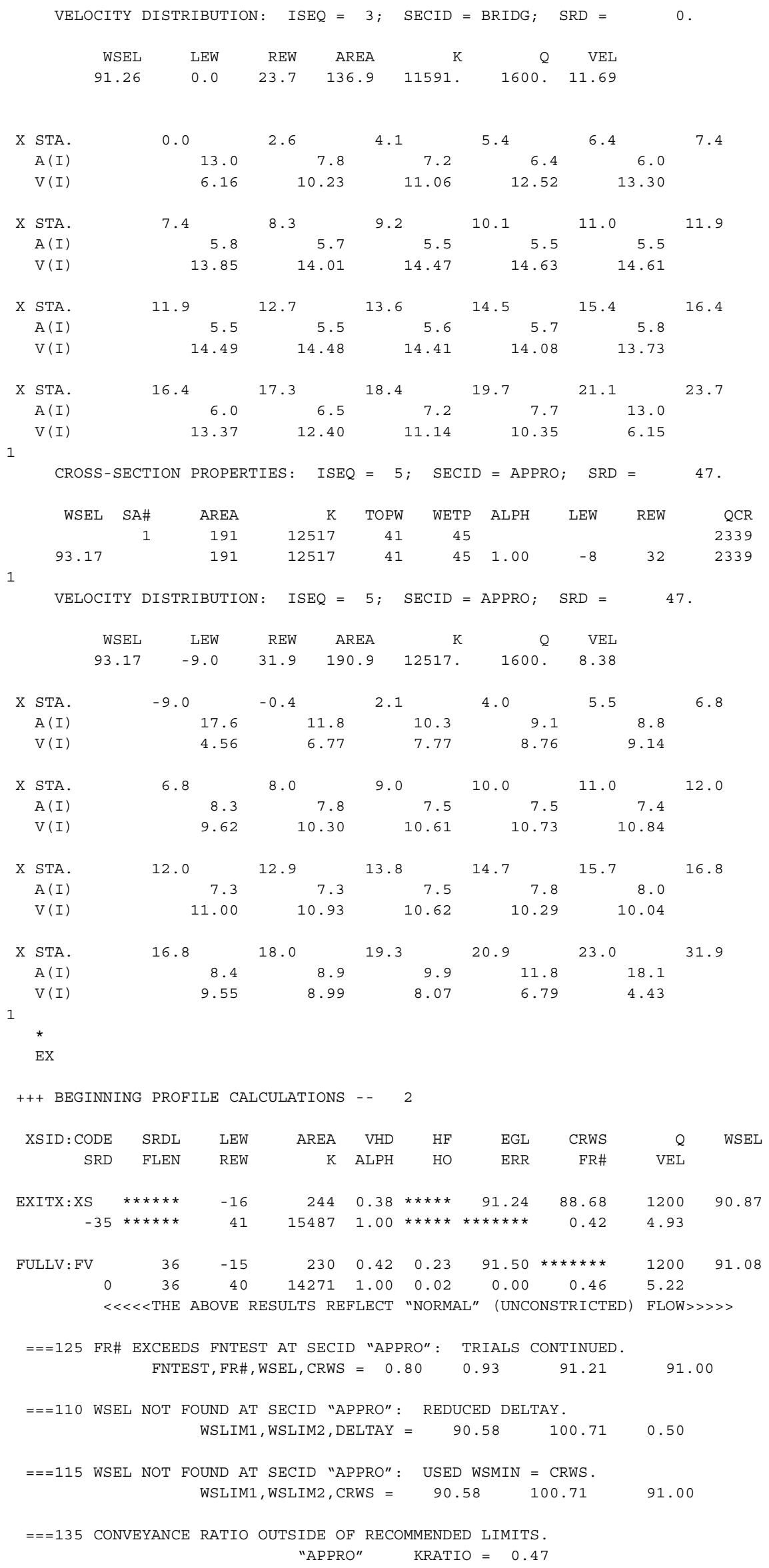


WSPRO OUTPUT FILE (continued)

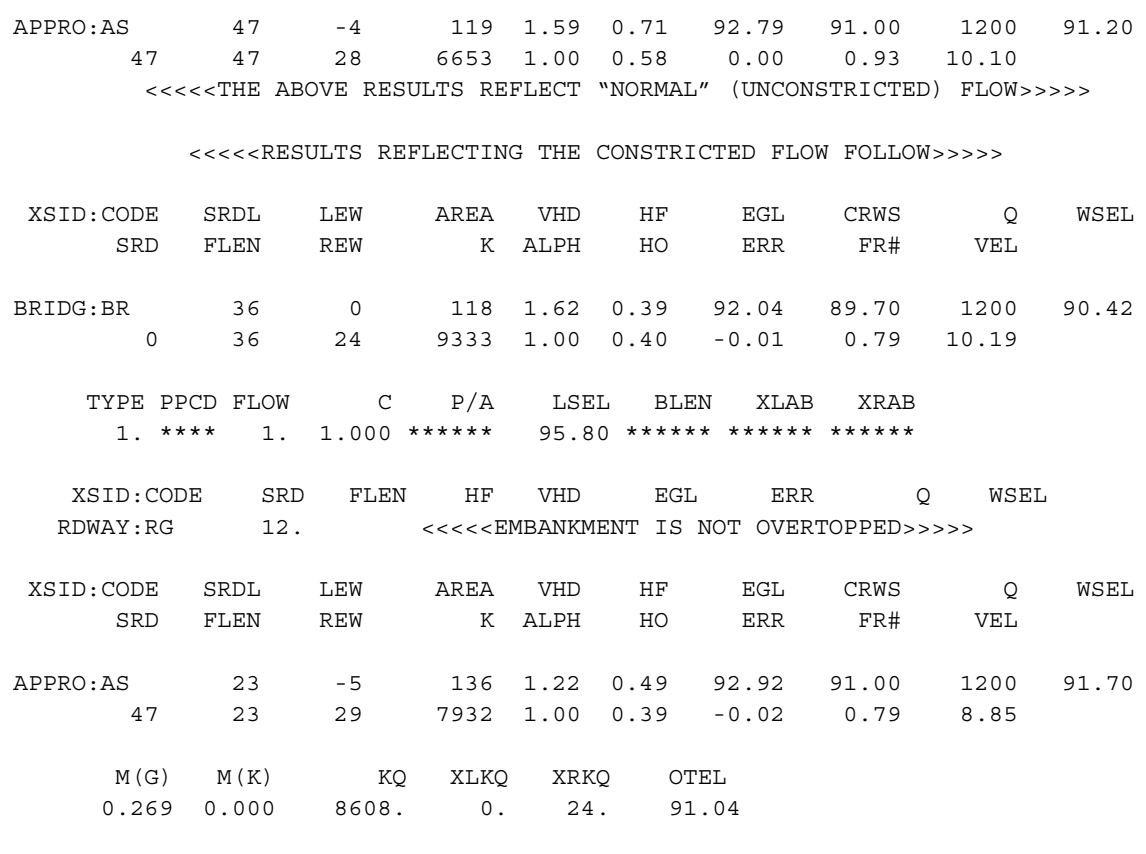

$<<<<$ END OF BRIDGE COMPUTATIONS $>>>>>$

FIRST USER DEFINED TABLE.

\begin{tabular}{|c|c|c|c|c|c|c|c|c|}
\hline XSID : CODE & SRD & LEW & REW & $Q$ & K & AREA & VEL & WSEL \\
\hline EXITX:XS & -36 & -17 & 41. & 1200. & 15487 . & 244 & 4.93 & 90.87 \\
\hline FULLV : FV & 0 . & -16 & 40. & 1200. & 14271 . & 230. & 5.22 & 91.08 \\
\hline BRIDG : BR & 0 . & 0 . & 24 . & 1200. & 9333. & 118. & 10.19 & 90.42 \\
\hline RDWAY : RG & \multicolumn{3}{|c|}{$12 . * * \star * * * * * * * \star * * *$} & \multicolumn{3}{|c|}{ 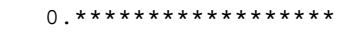 } & \multicolumn{2}{|c|}{$2.00 * * * * * * * *$} \\
\hline APPRO : AS & 47. & -6 & 29. & 1200. & 7932. & 136. & 8.85 & 91.70 \\
\hline XSID : CODE & XLKQ & XRKQ & & & & & & \\
\hline APPRO:AS & 0 . & 24 . & 8608 & & & & & \\
\hline
\end{tabular}

SECOND USER DEFINED TABLE.

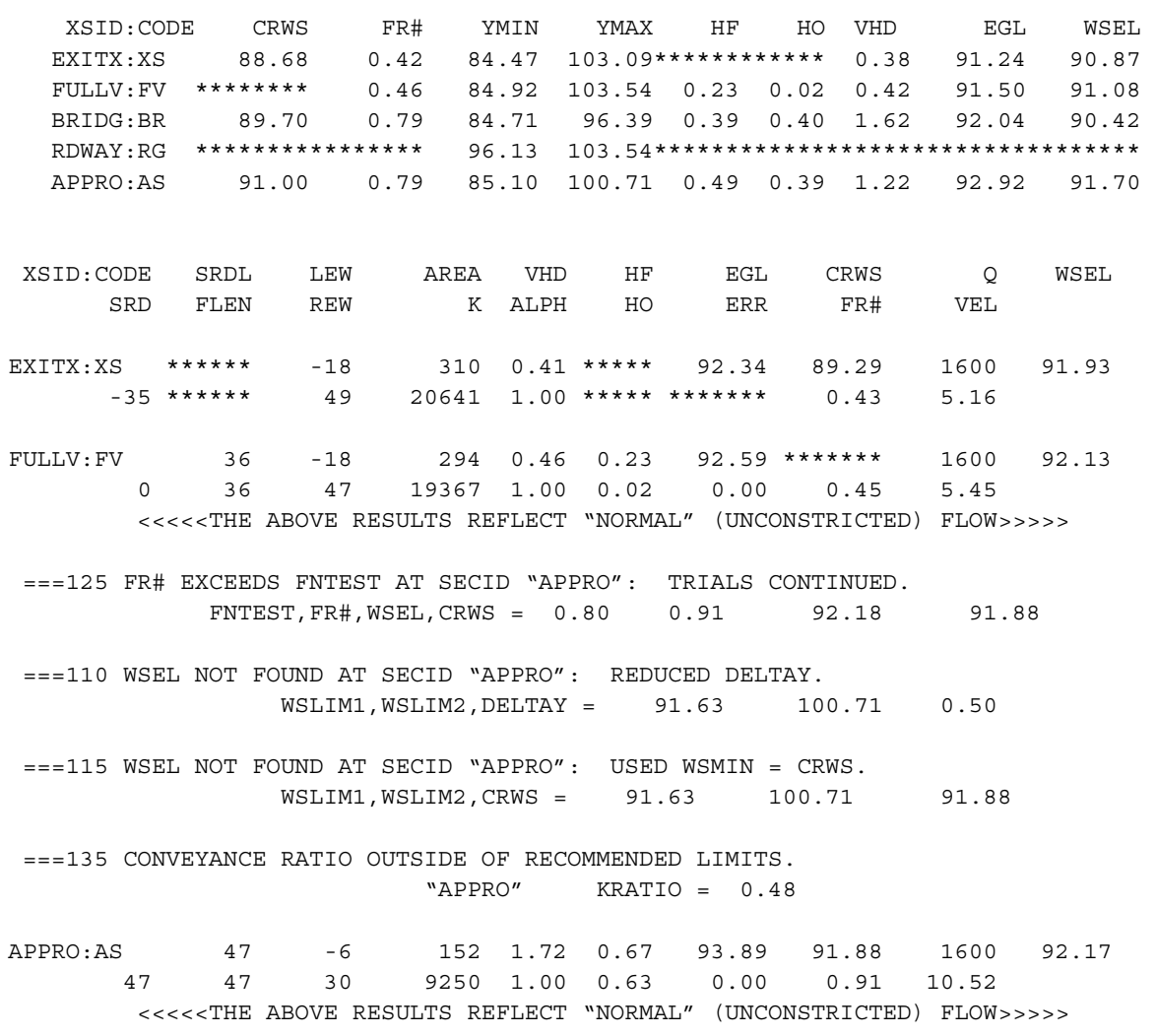


WSPRO OUTPUT FILE (continued)

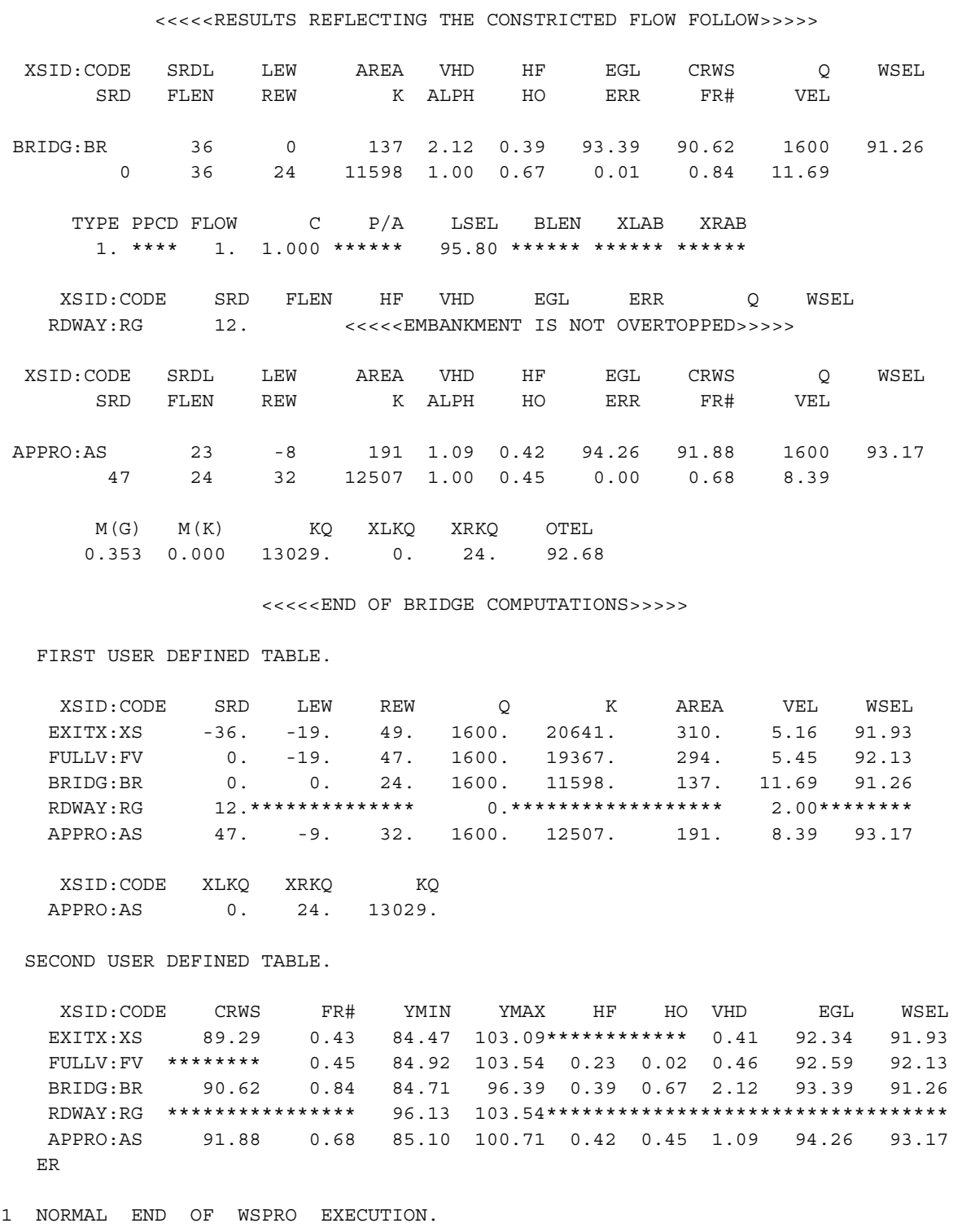




\section{APPENDIX C:}

\section{BED-MATERIAL PARTICAL-SIZE DISTRIBUTION}




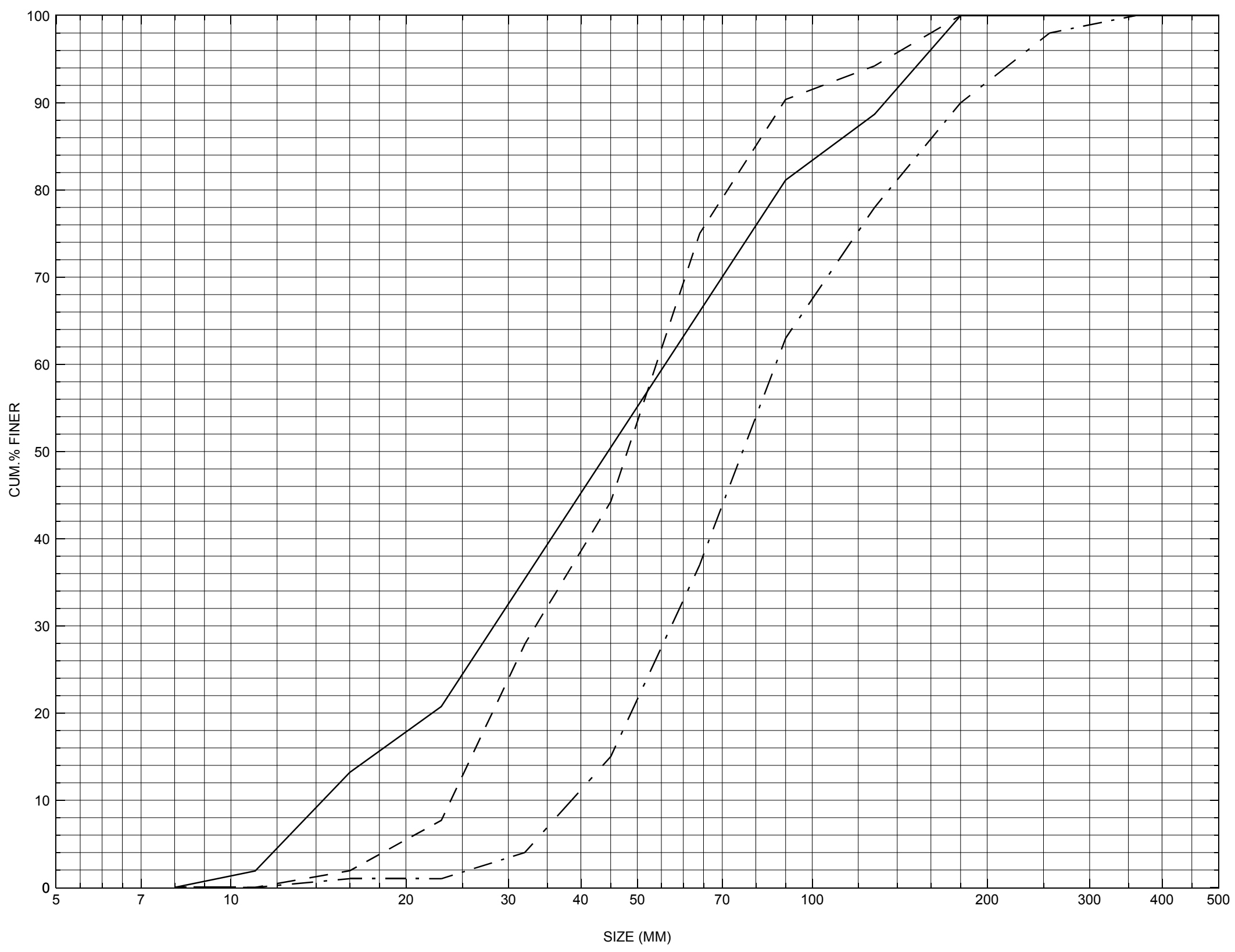

Appendix C. Bed material particle-size distributions for three pebble count transects at the approach cross-section for structure BRNATH00470031, in Barnard, Vermont. 


\section{APPENDIX D: \\ HISTORICAL DATA FORM}

